\title{
Editorial: Getting and Spending
}

Most editorial space is of course reserved for questions of national and international and cosmic importance, such as 'Whither philosophy?' and 'Why philosophy?' and 'Whether philosophy?' and 'How many brains make a drain?' But we also serve as a parish magazine for Gordon Square, giving news and notes of comings and goings, toings and froings, gettings and spendings, at the headquarters of the Institute. To paraphrase Ezra Pound, we join these words for hundreds of people, and allow the world, or at least the philosophical world, to eavesdrop on our conversation.

It happens that one of the main preoccupations of the Royal Institute of Philosophy in recent months and years has been eponymously mondial - the 18th World Congress of Philosophy at Brighton in August 1988. Our last editorial gave some account of the ambience and the proceedings of the Congress. Here we may fittingly record the contribution that the Institute made to the establishment of it in the United Kingdom and to its planning and programme and organization and finances.

The Institute was the prime sponsor of the Congress, but had the valuable co-operation and support of the British Academy, the Aristotelian Society, the Mind Association, the Society for Applied Philosophy, and the principal philosophical societies of Scotland, Wales and Ireland. The President of the Institute, the Earl of Halsbury, led a fund-raising campaign, and in the later stages served as President of some of the main committees of the Congress. Professor H. D. Lewis, Chairman of our Council, contributed substantially to the planning and the programme of the Congress. The main burdens of administration and organization, both in advance and during the week in Brighton, were borne by the Director, Professor A. Phillips Griffiths, the Secretary, Dr Mary Tiles, and Mr Martin Warner, a member of the Council and the Executive. In all their tasks they had the professional assistance of Conference Services Ltd, and we all had reason to be grateful to Miss Christine Philbin and her colleagues and staff.

The contribution of Professor Phillips Griffiths was particularly heavy, especially because of the unexpected and unprecedented media coverage given to the Congress in an August 'silly season' that was barren of more portentous international news. His declaration that 'Philosophy boils no cabbages' became so famous so quickly that it had to be officially denied by Professor Hare. The Director's dictum will 


\section{Editorial}

long be remembered, and so will his amiable and effective government of the week's arrangements, and the sense of style that he brought to the public portion of his varied responsibilities.

When benefits are counted, there must also be a counting of costs. When such a Congress takes place in Montreal (as it did in 1983) or in Moscow (as it will in 1993) or in East Germany (as it nearly did in 1988) the relevant government makes a grant to cover all the costs not covered by the subscriptions of the participants. On the present occasion there was an encouraging but somewhat symbolic grant from Her Majesty's Government through the Department of Education and Science, as well as grants from the British Academy and the Aristotelian Society. The Institute made a substantial donation, and some handsome contributions were added by Lord Halsbury's solicitations in the world of industry and commerce. The total amounted to nothing approaching the sum that Canada or the USSR or the German Democratic Republic provided or will provide or would have provided. There was a difficult decision to make about the level of subscriptions to be set in relation to uncertain estimates of numbers of philosophers likely to register at various hypothetical rates.

In the end there was an excess of expenditure over income that will significantly but not disastrously or even cripplingly deplete the reserves of the Institute, which have been built up so impressively in recent years by the Treasurer, Mr R. J. Newton.

Some of those who took prominent parts in this story are now passing on to other spheres. Professor Lewis has retired from the Chairmanship of the Council after a long, dedicated and distinguished service to the Institute. Dr Tiles has taken up a visiting Professorship at Swarthmore College in Pennsylvania. We thank her for her outstanding contribution to the organization of the Congress and for the great value of her work at Gordon Square.

We are happy to welcome Miss Joan Morris, formerly Secretary to the Department of Philosophy at the University of Reading, who took office as Secretary of the Institute in September 1988. Professor Lewis is succeeded as Chairman of the Council by Professor Stewart Sutherland, Principal of King's College London. The new Vice-Chairman is Professor Godfrey Vesey, Fellow and formerly Director of the Institute.

News was brought to us during the Congress that Messrs Adlard and Son Ltd, printers of Philosophy since 1973, had ceased trading. After a management buy-out it has proved possible to employ the successor firm Precise Printing \& Communications Ltd. Mr Westgate and $\mathrm{Mr}$ Taylor are old friends of the journal from the days of the former company. Change but not decay in all around we see. 